\title{
An Unsettled Debate About the Potential Role of Infection in Pathogenesis of Atherosclerosis
}

\author{
Udip Dahal $^{\mathrm{a}, \mathrm{d}}$, Dikshya Sharma ${ }^{\mathrm{b}}$, Kumud Dahal $^{\mathrm{c}}$
}

\begin{abstract}
Association of infection with atherosclerosis is by no means new. Several sero-epidemiological and pathologic studies as well as animal models have shown a link between infection and atherosclerosis Exciting discoveries in recent times related to role of inter-individual genetic variation in modulating inflammatory response to infection have reignited the enthusiasm in proving a causal link between infection and atherosclerosis. The purpose of this article was to review and analyze the available evidence linking infection with atherosclerosis.
\end{abstract}

Keywords: Multifactorial; Inflammatory; Antibiotics

\section{Introduction}

Atherosclerosis is a multifactorial disease with several clinical manifestations like coronary artery disease (CAD), acute myocardial infarction (MI) and stroke [1]. Role of traditional risk factors like age, sex, hypertension (HTN), diabetes mellitus (DM), smoking and dyslipidemia in atherosclerosis has been well established [2]. Cumulatively, these risk factors have a better ability to predict future risk than any single risk factor but they are not sufficient enough to explain the total burden of cardiovascular (CV) heart disease in the population [2-5]. Many human as well as animal models studies have shown relation between infection and atherosclerosis [6]. Infectious agents by evoking cellular and molecular changes provide a major stimulus for initiation and propagation of inflammation, an important mechanism involved in atherosclerosis [7-9]. Although negative outcomes of antibiotics trials have raised the

Manuscript accepted for publication April 12, 2017

aDepartment of Medicine, University of Utah, $50 \mathrm{~N}$ Medical Drive, Salt Lake City, UT, USA

${ }^{b}$ Department of Internal Medicine, Staten Island University Hospital, 475 Seaview Avenue, Staten Island, NY, USA

'Department of Infectious Disease, University of Illinois College of Medicine at Peoria, 1 Illinoi Drive, Peoria, IL, USA

${ }^{\mathrm{d} C o r r e s p o n d i n g ~ A u t h o r: ~ U d i p ~ D a h a l, ~ D e p a r t m e n t ~ o f ~ M e d i c i n e, ~ U n i v e r s i t y ~ o f ~}$ Utah, 50 N Medical Drive, Salt Lake City, UT, USA.

Email: drudip@gmail.com

doi: https://doi.org/10.14740/jocmr3032w question of role of infection as an inflammatory stimulus in pathophysiology of atherosclerosis, infection hypothesis continues to fascinate researchers because instead of ruling out the role of traditional risk factors, infections act through or in concert with them $[10,11]$.

\section{Mechanism of Atherosclerosis}

Atherosclerosis is a disease of blood vessels where both innate and adaptive immune systems are involved and inflammation plays a crucial role at all stages of it $[6,9,12,13]$. Histologically, normal arteries have trilaminar structure: tunica intima (single layered endothelium with its basement membrane and subendothelial space), tunica media (smooth muscle cells) and tunica adventitia (mast cells, nerve endings and microvessels) [14]. A primary initiating event in atherosclerosis is accumulation of low-density lipoprotein (LDL) after oxidative modification in subendothelial space which stimulates overlying endothelial cells to produce adhesion molecules, chemotactic proteins like monocyte chemotactic protein-1 (MCP-1) and growth factor like macrophage colony-stimulating factor (M-CSF) resulting in migration of monocytes into subendothelial space $[12,15]$. Monocytes differentiate into macrophages which uptake oxidized LDL, a process mediated by a number of scavenger receptors like SR-A and CD36, leading to formation of foam cells which are the building blocks of fatty streaks [16-18]. Fatty streaks could progress into atherosclerotic plaque which is composed of two elements: a small lipid core composed of modified lipids, macrophages and $\mathrm{T}$ cells and a fibrous cap made up of vascular smooth muscles, smooth muscle cells derived extracellular matrix and inflammatory cells like macrophage foam cells $[12,19]$. These atherosclerotic plaques could either erode or rupture causing thrombus formation and leading to acute coronary events $[18,19]$. Plaque rupture is mainly dependent on size of lipid rich core, thickness of fibrous cap and inflammation within the cap $[19,20]$.

Many cytokines such as interleukin (IL)-1, IL-6, IL-10, IFN-Y and TNF-Y are expressed highly in atherosclerotic lesions and an imbalance between pro- and inflammatory cytokines is known to be associated with atherosclerotic plaque growth and rupture $[9,21]$. High plasma levels of IFN-Y and TNF are associated with development of unstable plaques susceptible to rupture, whereas a high level of IL-10 has strong anti-inflammatory and atheroprotective effects [9, 17, 22, 23]. Discovery of a critical role played by Toll receptors in onset 
and progression of atherosclerosis has been an important step in unraveling molecular mechanism of atherosclerosis [24]. NF$\mathrm{kB}$ activation is essential in regulating different genes involved in inflammation and proliferation of cells critical to atherogenesis [25]. Toll like receptor and IL-1R-associated kinase (TLR- IRAK) signaling pathways by activating NF-kB induce transcription of inflammatory cytokine and chemokine genes critical to initiation and progression of atherosclerosis [26].

\section{Infection, Molecular Mimicry and Atherosclero- sis}

There is ample evidence to suggest that infection-induced immune-mediated reactions contribute to atherosclerosis [27]. Molecular mimicry, a host immune response initiated against invading pathogens with significant homology to host proteins cross-reacting with host structures, has been proposed to explain the link between infection and atherosclerosis [28]. Studies identifying autoantibodies to heat shock proteins (HSPs), a group of intracellular proteins whose expression to cellular surface of vascular endothelial cells increases in response to stress, in patients with atherosclerosis have increased the importance of molecular mimicry [29-31]. Several micro-organisms (Chlamydia pneumoniae (Cpn), E. coli, and mycobacteria) express homologus forms of HSPs [32]. These stress proteins acting as key target antigens recruit $\mathrm{T}$ lymphocytes from general circulation to vessel wall and by transforming Th1 dominant T lymphocytes contribute to foam cell formation [27, 31, 33].

\section{Infection Has Been Linked to Atherosclerosis at an Early Age}

Role of acute infections in producing coronary intimal thickenings were observed in autopsied older infants and children $[34,35]$. Healthy children with persistent antibodies against Cpn were found to have an increase in intima media thickness (probably reflecting increased fatty streak formation) suggesting a role of infection in early atherosclerosis [36]. Similarly, in a longitudinal population-based study done in Australia, severe childhood infection was associated with subsequent hospitalization in adulthood from ischemic heart disease (IHD), ischemic stroke and peripheral vascular disease independent of population level risk factors further strengthening the role of infection in atherosclerosis and CV heart disease [37].

\section{Acute Infections and Atherosclerosis/CV Dis- ease}

Acute infections by inducing inflammation affect atherosclerotic disease [38]. Studies have associated acute respiratory tract infection, urinary tract infection and bacteremia with acute coronary syndrome (ACS) [39-44]. This association is strongest for acute respiratory tract infection, in particular influenza, and our discussion will be limited to it.

\section{Influenza}

Several studies (mainly retrospective and one prospective) have suggested that acute respiratory infections can trigger acute MI [45-48]. It is now widely recognized that influenza epidemics are responsible for an increase in acute $\mathrm{MI}$ and excess deaths from IHD [49]. Autopsy study has proved this association [50]. Observational studies with the use of oseltamivir in patients with history of $\mathrm{CV}$ disease infected with influenza have shown a reduction in subsequent acute cardiac events [51]. These observations and studies make association of influenza with ACS fascinating.

In order to explain the mechanism by which influenza virus causes atherosclerosis, animal models have been created. In lipoprotein E-deficient ( $\mathrm{apoE}^{-/}$) mouse model, a standard model to study atherosclerosis, influenza infection induced heavy infiltration of atherosclerotic plaques by inflammatory cells as well as fibrin deposition and thrombus formation [52]. Similarly, following inoculation with influenza, influenza viral antigens were detected in atherosclerotic plaque among apoE-deficient mice but not in non-virus inoculated control animals [53]. Viable influenza virus was recovered from aorta of normal and atherosclerotic mice in absence of viremia after infection with influenza indicating contribution of influenza infection to atherosclerosis [53]. Influenza virus is also known to cause a prothrombotic state by increasing thrombin generation and destabilization of vulnerable atherosclerotic plaque by increasing number of proinflammatory and prothrombotic cytokines $[54,55]$. High levels of inflammatory cytokines and chemokines in plasma were found in patients with influenza A (H7N9) and H5N91 and they co-related with severe clinical outcomes including death [56, 57]. Finally, influenza vaccine was found to reduce major $\mathrm{CV}$ events in patients with ACS $[58,59]$. Successful outcomes of influenza vaccination for $\mathrm{CV}$ patients were recognized by AHA and ACC and influenza vaccination has been recommended in their guidelines as a part of secondary prevention for CV disease [60]. In animal model of mice, influenza vaccine was found to stabilize atherosclerotic plaque by lowering pro-inflammatory markers while favoring synthesis of anti-inflammatory cytokine IL-4 [61].

\section{Chronic Infections and Atherosclerosis}

The hypothesis that infectious agents are associated with development of atherosclerosis gained traction when Fabricant et al showed that Marek's disease virus, a chicken herpes virus, could induce atherosclerosis in chickens [62]. A wide variety of pathogens, both viruses and bacteria, have been identified as factors leading to a chronic inflammatory state and contributing to atherosclerosis. Most of these pathogens have some common features like being intracellular pathogens and able to establish persistent infection [63]. Evidence on involvement of these pathogens in atherosclerosis has been based on seroepidemiologic studies, detection of pathogens DNA in atherosclerotic plaque, isolation of pathogens from atherosclerotic lesions and in vitro/in vivo studies demonstrating direct role of pathogens at various stages of atherosclerosis. Among these 
pathogens, cytomegalovirus (CMV) and Cpn have been studied extensively and we will review the available data on them including pathogenetic mechanisms.

\section{CMV}

Strong evidence for association of CMV with native coronary vessel atherosclerosis comes from a prospective epidemiological study, the ARIC study, where high levels of antibody to CMV were significantly associated with incident CV disease [64]. During 9 years of follow-up in the elderly Latino community, high CMV I $\mathrm{G}$ antibody titers which correlated with elevated TNF-alpha and IL-6 levels were associated with increased $\mathrm{CV}$ deaths suggesting a relationship between ongoing inflammation, high CMV titers and observed mortality [65]. Elevated CMV antibody titers were associated with an increased risk of carotid intimal-medial thickening, a measure of subclinical atherosclerosis after 13 - 18 years in one longitudinal prospective study [66]. CMV seropositivity was also found to be an important predictor of coronary restenosis after coronary angioplasty. Forty-three percent of CMV seropositive patients had restenosis at 6 months compared with $8 \%$ of CMV seronegative patients [67]. In the realm of transplantation, an increased rate of atherosclerotic events was observed in patients with post-transplant CMV replication compared to those without replication [68]. Several other sero-epidemiological studies have also linked CMV infection with post-transplant atherosclerosis $[69,70]$. Not all studies, however, show a positive association between CMV seropositivity and CAD. In a large cohort of nearly 900 successive non-transplant patients undergoing coronary angiography, CMV infection was not found to be a major risk factor for development of primary CAD defined as greater than $50 \%$ of blockage in any coronary arteries [71]. Since the control group in this study comprised of patients with clinical indication for angiography, many of them who were found to have positive antibodies to CMV probably had some atherosclerosis. Some other prospective studies evaluating CMV seropositivity and risk of future CV events (including MI and death) in middle-aged individuals and older adults have failed to show a positive association [7274]. A careful analysis of these studies, however, reveals that CMV titers had not been measured quantitatively and CMV seropositivity was used solely as a dichotomous variable [75]. Quantification of antibody titer could be important since one of the cross-sectional studies done in young aged individuals found that seropositivity to CMV in itself was not associated with risk of premature MI but a titer of anti-CMV I $\mathrm{G}$ greater than $100 \mathrm{EU} / \mathrm{mL}$ was associated with an increased risk of premature MI [76]. Since different studies utilize different clinical outcomes along the spectrum of disease progression and severity, a great amount of caution should be needed while interpreting and comparing the results of different studies [75].

\section{Isolation of CMV From Atherosclerotic Plaque}

If $\mathrm{CMV}$ were to be considered in the pathogenesis of ath- erosclerosis, a vascular tropism for CMV at sites prone for atherosclerotic lesions needs to be demonstrated. But the available studies on the frequency of CMV DNA in human atherosclerotic plaques have become confusing. While some studies show CMV DNA to be highly prevalent, others could not detect any CMV DNA [77]. A study done by Hendrix and his colleagues found that in CMV seropositive patients, CMV nucleic acids were equally distributed among arteries with and without atherosclerotic changes [78]. Recent studies however have identified CMV DNA in atherosclerotic plaques and not in non-atherosclerotic vessels [77, 79].

\section{Animal Models for CMV}

To study the role of infections in atherosclerotic process, animal models are a necessity. ApoE participates in hepatic clearance of cholesterol rich LDL from plasma and when it is knocked out in mice they acquire high plasma cholesterol levels and demonstrate progressive series of atherogenic events similar to humans making this model suitable for studying genetic and environmental influences on atherosclerotic process [80]. Chronic infection of apoE knockout mice with murine CMV increased atherosclerotic lesion size by both direct (increased production of pro-inflammatory cytokines and presence of murine CMV DNA in the lesion) and indirect effects (increasing systemic pro-inflammatory cytokines) [81]. Even injection of non-infectious virus (ultraviolet inactivation of murine CMV) caused an acceleration of atherosclerotic lesions in apoE knockout mice suggesting a possible immune-mediated aggravation of atherosclerosis [82]. Some of the mechanisms involved in initiation and progression of atherosclerotic disease by CMV include inflammatory cell influx (mainly $\mathrm{T}$ lymphocytes), intimal thickening by stimulating smooth muscle cell proliferation and increased aortic expression of proatherosclerotic genes selectively recruiting monocytes by upregulating chemokines (MCP-1 expression) [83-85].

\section{Cpn}

Cpn is probably one of the most extensively studied microorganisms in an effort to prove association of infections with atherosclerosis. Saikku et al have reported an association between Cpn infection and coronary atherosclerosis for the first time in 1988 [86]. Since then there have been multiple sero-epidemiologic studies with contradictory results. The studies were done in different populations using different criteria for cases or various cutoff titers to define seropositivity and have been adjusted for potential confounders to varying degrees making them susceptible to different kinds of biases [87]. One metaanalysis of 15 prospective trials evaluating $\mathrm{I}_{\mathrm{g}} \mathrm{G}$ titers involving over 3,000 cases and over 9,000 controls found no significant association between $\mathrm{CAD}$ and $\mathrm{I}_{\mathrm{g}} \mathrm{G}$ titers [88]. Another metaanalysis of 10 prospective trials evaluating $\mathrm{I}_{\mathrm{g}} \mathrm{A}$ titers involving greater than 2,000 cases and over 7,000 controls found a significant but weak association with $\mathrm{I}_{\mathrm{g}} \mathrm{A}$ titers [89]. Cpn was detected in $50-62 \%$ of atheromatous plaques from symptomatic 
patients but was rarely detected in non-atherosclerotic tissues $[90,91]$. Viable chlamydiae have been isolated from primary atheromatous lesions as well as from secondary restenotic by pass lesions [92]. They were detected by electron microscopy in coronary artery fatty streaks and atheromatous plaques in autopsies [93]. Recently, higher density of Cpn cells was found to be more prevalent in plaques associated with ACS [94]. But the debate regarding whether they were causative pathogens or innocent bystanders persists. Etiologic significance of presence of Cpn in atheromatous lesions can be ascertained only after demonstrating its capability of either initiating or potentiating atherosclerosis in in vitro and in vivo studies. Based on in vitro studies, chlamydia was found to have the ability to infect, proliferate and maintain its infectivity in cells that are common components of atherosclerotic plaque like endothelial cells, macrophages and smooth muscle cells $[95,96]$. Cpn infection of cultured endothelial cells activates transcription factor NF-kB upregulating expression of several genes causing cell proliferation, inflammation and progression of atherosclerosis $[97,98]$. Chlamydia is also known to cause production of large amounts of chlamydial HSP60 (cHSP60) during chronic persistent infections [9]. cHSP60 by inducing TNF-alpha and MMP expression by macrophages increases endothelial expression of E-selectin, ICAM-1, VACM-1 and IL-6, whereas by activating NF-kB complexes it could contribute to atherogenesis and plaque instability $[99,100]$. HSP 60 of Cpn by inducing lectin like oxidized LDL receptor $1(\mathrm{LOX}-1)$ is known to mediate fatty streak formation in hypercholesterolemic rabbits [101]. In animal models like atherosclerosis prone apoE $\mathrm{E}^{-/-}$mice, chlamydia infection was able to result in acceleration of atherosclerosis [102]. Finally, chlamydia possesses ligands for both TLR4 and TLR2 and blocking them may have a beneficial effect on atherosclerosis [103]. All of these findings were convincing enough to suggest a strong association of $\mathrm{Cpn}$ with atherosclerosis/CV disease and this has led to the designing of several antibiotics trial in a hope of improving $\mathrm{CV}$ outcomes in CAD patients. Four large-scale randomized trials (WIZARD, ACES, CLARICOR and PROVE IT-TIMI) had studied the effects of antibiotics in prevention of composite $\mathrm{CV}$ events. Unfortunately, the results of these trials have been discouraging. A meta-analysis of antibiotic trials has failed to detect a significant association between antibiotic use and secondary prevention of composite CV events [104]. The negative results of these trials have dampened the enthusiasm in associating infections with atherosclerosis and its complications [105]. But there are a number of things that need to be considered while interpreting the results of these antibiotic trials. First, the trials were secondary prevention studies and antibiotics will not be able to reverse or modify established pathology of advanced atherosclerosis [106, 107]. Second, if infection were to play a role in atherogenesis and its complications, pathogen burden (aggregate pathogens including viruses and bacteria) would best correlate with this role and the chosen antibiotic might not be able to eradicate all the infections [105]. Lastly, given the role of complex immune-related and genetically manipulated mechanism in initiation and progression of atherosclerosis, antimicrobials combined with immunosuppressive medications as in other immune-mediated infection-induced complications like post-infectious glomerulonephritis and Guillain-Barre syndrome might achieve signifi- cant benefit than antibiotics alone [63].

Inflammatory and immune response modulating atherogenic effects of infection can vary based on genetic differences [63]. When mice with genetic deficiency of apoE was infected with Cpn, accelerated atherosclerosis and increased serum levels of pro-inflammatory cytokines were observed but when they had additional genetic deficiency in TLR2 and TLR4, atherosclerotic plaque development was significantly inhibited [102]. Patients with IL-1 gene polymorphism and Cpn seropositivity were found to be more likely to develop CAD than seropositive patients without IL-1 gene polymorphism [108]. Further research into the role of genetic variation in modulating the atherogenic effects of infection could be instrumental in clarifying the association between infection with atherosclerosis.

\section{Pathogen Burden and Atherosclerosis}

The concept of pathogen burden which means cumulative burden of infection rather than one specific infection is an emerging one in the pathogenesis of atherosclerosis [109, 110]. Zhu et al first demonstrated that increasing pathogen burden instead of an individual pathogen contributes to atherosclerosis. CAD prevalence was $77 \%$ higher in the group with antibodies to five pathogens (CMV, hepatitis A virus, Cpn, herpes simplex virus-1 and herpes simplex virus-2) compared with the group with antibodies to two or less than two pathogens [111]. In a prospective study, researchers studied impact of pathogen burden on long-term prognosis in patients with CAD and found that aggregate number of pathogens was more predictive of future fatal CV events [112]. Simultaneous detection of two pathogens in atherosclerotic lesions and demonstration of synergistic effect of different pathogens on expression of atherosclerotic factors like IL-6, IL-8, etc, in vascular smooth muscle cells involved in formation of atherosclerotic plaque further support the hypothesis of pathogen burden [113, 114]. Role of pathogen burden in the pathogenesis of atherosclerosis has probably been underestimated and further research will be needed to clarify this complex association [115].

\section{Summary}

Based on the available evidence, there is no doubt that infections do play a role in atherosclerosis and its complications. How infections play a role in atherosclerosis and at what point of its natural history is still controversial. Given the complex nature of atherosclerosis initiation and progression, even when infections were found to be causally related to atherosclerosis, whether eradicating them could result in significant benefit in terms of clinical outcome is yet to be determined. More research in the years ahead is needed to clarify the role of infection in atherosclerosis.

\section{Competing Interests}

The authors declare that they have no competing interests. 


\section{Author Contributions}

Udip Dahal made substantial contributions to conception and design, or acquisition of data, or analysis and interpretation of data. Dikshya Sharma was involved in drafting and revising the manuscript. Kumud Dahal made the final approval of the version to be published.

\section{References}

1. Singh RB, Mengi SA, Xu YJ, Arneja AS, Dhalla NS. Pathogenesis of atherosclerosis: A multifactorial process. Exp Clin Cardiol. 2002;7(1):40-53.

2. Fruchart JC, Nierman MC, Stroes ES, Kastelein JJ, Duriez P. New risk factors for atherosclerosis and patient risk assessment. Circulation. 2004;109(23 Suppl 1):III1519.

3. Berry JD, Dyer A, Cai X, Garside DB, Ning H, Thomas A, Greenland P, et al. Lifetime risks of cardiovascular disease. N Engl J Med. 2012;366(4):321-329.

4. Berenson GS, Srinivasan SR, Bao W, Newman WP, 3rd, Tracy RE, Wattigney WA. Association between multiple cardiovascular risk factors and atherosclerosis in children and young adults. The Bogalusa Heart Study. N Engl J Med. 1998;338(23):1650-1656.

5. Verschuren WM, Jacobs DR, Bloemberg BP, Kromhout D, Menotti A, Aravanis C, Blackburn H, et al. Serum total cholesterol and long-term coronary heart disease mortality in different cultures. Twenty-five-year follow-up of the seven countries study. JAMA. 1995;274(2):131-136.

6. Libby P, Egan D, Skarlatos S. Roles of infectious agents in atherosclerosis and restenosis: an assessment of the evidence and need for future research. Circulation. 1997;96(11):4095-4103.

7. Epstein SE, Zhou YF, Zhu J. Infection and atherosclerosis: emerging mechanistic paradigms. Circulation. 1999;100(4):e20-28.

8. Libby P, Ridker PM, Maseri A. Inflammation and atherosclerosis. Circulation. 2002;105(9):1135-1143.

9. Tedgui A, Mallat Z. Cytokines in atherosclerosis: pathogenic and regulatory pathways. Physiol Rev. 2006;86(2):515-581.

10. Anderson JL. Infection, antibiotics, and atherothrombosis - end of the road or new beginnings? N Engl J Med. 2005;352(16):1706-1709.

11. Mattila KJ, Valtonen VV, Nieminen MS, Asikainen $\mathrm{S}$. Role of infection as a risk factor for atherosclerosis, myocardial infarction, and stroke. Clin Infect Dis. 1998;26(3):719-734.

12. Lusis AJ. Atherosclerosis. Nature. 2000;407(6801):233241.

13. Hansson GK, Hermansson A. The immune system in atherosclerosis. Nat Immunol. 2011;12(3):204-212.

14. Owens CD. Atherosclerosis. Rutherford's vascular surgery 2014; chapter 5: 66-67.

15. Libby P, Ridker PM, Hansson GK. Progress and challenges in translating the biology of atherosclerosis. Nature.
2011;473(7347):317-325.

16. Hansson GK, Robertson AK, Soderberg-Naucler C. Inflammation and atherosclerosis. Annu Rev Pathol. 2006;1:297-329.

17. McLaren JE, Ramji DP. Interferon gamma: a master regulator of atherosclerosis. Cytokine Growth Factor Rev. 2009;20(2):125-135.

18. Fuster V, Moreno PR, Fayad ZA, Corti R, Badimon JJ. Atherothrombosis and high-risk plaque: part I: evolving concepts. J Am Coll Cardiol. 2005;46(6):937-954.

19. Thim T, Hagensen MK, Bentzon JF, Falk E. From vulnerable plaque to atherothrombosis. $\mathrm{J}$ Intern Med. 2008;263(5):506-516.

20. Falk E, Shah PK, Fuster V. Coronary plaque disruption. Circulation. 1995;92(3):657-671.

21. Mehra VC, Ramgolam VS, Bender JR. Cytokines and cardiovascular disease. J Leukoc Biol. 2005;78(4):805818.

22. Zhang L, Peppel K, Sivashanmugam P, Orman ES, Brian L, Exum ST, Freedman NJ. Expression of tumor necrosis factor receptor-1 in arterial wall cells promotes atherosclerosis. Arterioscler Thromb Vasc Biol. 2007;27(5):10871094.

23. Potteaux S, Esposito B, van Oostrom O, Brun V, Ardouin $\mathrm{P}$, Groux H, Tedgui A, et al. Leukocyte-derived interleukin 10 is required for protection against atherosclerosis in low-density lipoprotein receptor knockout mice. Arterioscler Thromb Vasc Biol. 2004;24(8):1474-1478.

24. Chtarbanova S, Imler JL. Microbial sensing by Toll receptors: a historical perspective. Arterioscler Thromb Vasc Biol. 2011;31(8):1734-1738.

25. Brand K, Page S, Walli AK, Neumeier D, Baeuerle PA. Role of nuclear factor-kappa B in atherogenesis. Exp Physiol. 1997;82(2):297-304.

26. Kim TW, Febbraio M, Robinet P, Dugar B, Greene D, Cerny A, Latz E, et al. The critical role of IL-1 receptor-associated kinase 4-mediated NF-kappaB activation in modified low-density lipoprotein-induced inflammatory gene expression and atherosclerosis. J Immunol. 2011;186(5):2871-2880.

27. Epstein SE, Zhu J, Burnett MS, Zhou YF, Vercellotti G, Hajjar D. Infection and atherosclerosis: potential roles of pathogen burden and molecular mimicry. Arterioscler Thromb Vasc Biol. 2000;20(6):1417-1420.

28. Albert LJ, Inman RD. Molecular mimicry and autoimmunity. N Engl J Med. 1999;341(27):2068-2074.

29. Blasi C. The autoimmune origin of atherosclerosis. Atherosclerosis. 2008;201(1):17-32.

30. Morimoto RI. Cells in stress: transcriptional activation of heat shock genes. Science. 1993;259(5100):1409-1410.

31. Chan YC. Is heat shock protein the missing link between chlamydia pneumoniae infection and atherosclerosis? BMJ. 1999;318:1035.

32. Lamb DJ, El-Sankary W, Ferns GA. Molecular mimicry in atherosclerosis: a role for heat shock proteins in immunisation. Atherosclerosis. 2003;167(2):177-185.

33. Kol A, Sukhova GK, Lichtman AH, Libby P. Chlamydial heat shock protein 60 localizes in human atheroma and regulates macrophage tumor necrosis factor-alpha 
and matrix metalloproteinase expression. Circulation. 1998;98(4):300-307.

34. Minkowski WL. The coronary arteries of infants. Am J Med Sci. 1947;214(6):623-629.

35. Pesonen E. Coronary wall thickening in children. An analysis of the factors associated with the growth of arterial layers. Atherosclerosis. 1974;20(2):173-187.

36. Volanen I, Jarvisalo MJ, Vainionpaa R, Arffman M, Kallio K, Angle S, Ronnemaa T, et al. Increased aortic intima-media thickness in 11-year-old healthy children with persistent Chlamydia pneumoniae seropositivity. Arterioscler Thromb Vasc Biol. 2006;26(3):649-655.

37. Burgner DP, Cooper MN, Moore HC, Stanley FJ, Thompson PL, de Klerk NH, Carter KW. Childhood hospitalisation with infection and cardiovascular disease in earlymid adulthood: a longitudinal population-based study. PLoS One. 2015;10(5):e0125342.

38. Madjid M, Vela D, Khalili-Tabrizi H, Casscells SW, Litovsky S. Systemic infections cause exaggerated local inflammation in atherosclerotic coronary arteries: clues to the triggering effect of acute infections on acute coronary syndromes. Tex Heart Inst J. 2007;34(1):11-18.

39. Warren-Gash C, Smeeth L, Hayward AC. Influenza as a trigger for acute myocardial infarction or death from cardiovascular disease: a systematic review. Lancet Infect Dis. 2009;9(10):601-610.

40. Ramirez J, Aliberti S, Mirsaeidi M, Peyrani P, Filardo G, Amir A, Moffett B, et al. Acute myocardial infarction in hospitalized patients with community-acquired pneumonia. Clin Infect Dis. 2008;47(2):182-187.

41. Musher DM, Rueda AM, Kaka AS, Mapara SM. The association between pneumococcal pneumonia and acute cardiac events. Clin Infect Dis. 2007;45(2):158-165.

42. Sims JB, de Lemos JA, Maewal P, Warner JJ, Peterson GE, McGuire DK. Urinary tract infection in patients with acute coronary syndrome: a potential systemic inflammatory connection. Am Heart J. 2005;149(6):1062-1065.

43. Corrales-Medina VF, Fatemi O, Serpa J, Valayam J, Bozkurt B, Madjid M, Musher DM. The association between Staphylococcus aureus bacteremia and acute myocardial infarction. Scand J Infect Dis. 2009;41(6-7):511-514.

44. Smeeth L, Thomas SL, Hall AJ, Hubbard R, Farrington $\mathrm{P}$, Vallance P. Risk of myocardial infarction and stroke after acute infection or vaccination. $\mathrm{N}$ Engl J Med. 2004;351(25):2611-2618.

45. Bainton D, Jones GR, Hole D. Influenza and ischaemic heart disease - a possible trigger for acute myocardial infarction? Int J Epidemiol. 1978;7(3):231-239.

46. Spodick DH, Flessas AP, Johnson MM. Association of acute respiratory symptoms with onset of acute myocardial infarction: prospective investigation of 150 consecutive patients and matched control patients. Am J Cardiol. 1984;53(4):481-482.

47. Zheng ZJ, Mittleman MA, Tofler GH, et al. Infections prior to acute myocardial infarction onset. J Am Coll cardiol. 1998;31(suppl 1):132-133.

48. Meier CR, Jick SS, Derby LE, Vasilakis C, Jick H. Acute respiratory-tract infections and risk of first-time acute myocardial infarction. Lancet. 1998;351(9114):1467-
1471.

49. Fleming DM, Cross KW, Pannell RS. Influenza and its relationship to circulatory disorders. Epidemiol Infect. 2005;133(2):255-262.

50. Madjid M, Miller CC, Zarubaev VV, Marinich IG, Kiselev OI, Lobzin YV, Filippov AE, et al. Influenza epidemics and acute respiratory disease activity are associated with a surge in autopsy-confirmed coronary heart disease death: results from 8 years of autopsies in 34,892 subjects. Eur Heart J. 2007;28(10):1205-1210.

51. Casscells SW, Granger E, Kress AM, Linton A, Madjid $\mathrm{M}$, Cottrell L. Use of oseltamivir after influenza infection is associated with reduced incidence of recurrent adverse cardiovascular outcomes among military health system beneficiaries with prior cardiovascular diseases. Circ Cardiovasc Qual Outcomes. 2009;2(2):108-115.

52. Naghavi M, Wyde P, Litovsky S, Madjid M, Akhtar A, Naguib S, Siadaty MS, et al. Influenza infection exerts prominent inflammatory and thrombotic effects on the atherosclerotic plaques of apolipoprotein E-deficient mice. Circulation. 2003;107(5):762-768.

53. Haidari M, Wyde PR, Litovsky S, Vela D, Ali M, Casscells SW, Madjid M. Influenza virus directly infects, inflames, and resides in the arteries of atherosclerotic and normal mice. Atherosclerosis. 2010;208(1):90-96.

54. Keller TT, van der Sluijs KF, de Kruif MD, Gerdes VE, Meijers JC, Florquin S, van der Poll T, et al. Effects on coagulation and fibrinolysis induced by influenza in mice with a reduced capacity to generate activated protein $\mathrm{C}$ and a deficiency in plasminogen activator inhibitor type 1. Circ Res. 2006;99(11):1261-1269.

55. Madjid M, Aboshady I, Awan I, Litovsky S, Casscells SW. Influenza and cardiovascular disease: is there a causal relationship? Tex Heart Inst J. 2004;31(1):4-13.

56. Wang Z, Zhang A, Wan Y, Liu X, Qiu C, Xi X, Ren Y, et al. Early hypercytokinemia is associated with interferoninduced transmembrane protein-3 dysfunction and predictive of fatal H7N9 infection. Proc Natl Acad Sci U S A. 2014;111(2):769-774.

57. de Jong MD, Simmons CP, Thanh TT, Hien VM, Smith GJ, Chau TN, Hoang DM, et al. Fatal outcome of human influenza $\mathrm{A}(\mathrm{H} 5 \mathrm{~N} 1)$ is associated with high viral load and hypercytokinemia. Nat Med. 2006;12(10):1203-1207.

58. Naghavi M, Barlas Z, Siadaty S, Naguib S, Madjid M, Casscells W. Association of influenza vaccination and reduced risk of recurrent myocardial infarction. Circulation. 2000;102(25):3039-3045.

59. Phrommintikul A, Kuanprasert S, Wongcharoen W, Kanjanavanit R, Chaiwarith R, Sukonthasarn A. Influenza vaccination reduces cardiovascular events in patients with acute coronary syndrome. Eur Heart J. 2011;32(14):17301735 .

60. Smith SC, Jr., Allen J, Blair SN, Bonow RO, Brass LM, Fonarow GC, Grundy SM, et al. AHA/ACC guidelines for secondary prevention for patients with coronary and other atherosclerotic vascular disease: 2006 update: endorsed by the National Heart, Lung, and Blood Institute. Circulation. 2006;113(19):2363-2372.

61. Bermudez-Fajardo A, Oviedo-Orta E. Influenza vacci- 
nation promotes stable atherosclerotic plaques in apoE knockout mice. Atherosclerosis. 2011;217(1):97-105.

62. Buja LM. Does atherosclerosis have an infectious etiology? Circulation. 1996;94(5):872-873.

63. Chatzidimitriou D, Kirmizis D, Gavriilaki E, Chatzidimitriou M, Malisiovas N. Atherosclerosis and infection: is the jury still not in? Future Microbiol. 2012;7(10):12171230.

64. Sorlie PD, Nieto FJ, Adam E, Folsom AR, Shahar E, Massing M. A prospective study of cytomegalovirus, herpes simplex virus 1, and coronary heart disease: the atherosclerosis risk in communities (ARIC) study. Arch Intern Med. 2000;160(13):2027-2032.

65. Roberts ET, Haan MN, Dowd JB, Aiello AE. Cytomegalovirus antibody levels, inflammation, and mortality among elderly Latinos over 9 years of follow-up. Am J Epidemiol. 2010;172(4):363-371.

66. Nieto FJ, Adam E, Sorlie P, Farzadegan H, Melnick JL, Comstock GW, Szklo M. Cohort study of cytomegalovirus infection as a risk factor for carotid intimal-medial thickening, a measure of subclinical atherosclerosis. Circulation. 1996;94(5):922-927.

67. Zhou YF, Leon MB, Waclawiw MA, Popma JJ, Yu ZX, Finkel T, Epstein SE. Association between prior cytomegalovirus infection and the risk of restenosis after coronary atherectomy. N Engl J Med. 1996;335(9):624-630.

68. Courivaud C, Bamoulid J, Chalopin JM, Gaiffe E, Tiberghien P, Saas P, Ducloux D. Cytomegalovirus exposure and cardiovascular disease in kidney transplant recipients. J Infect Dis. 2013;207(10):1569-1575.

69. Grattan MT, Moreno-Cabral CE, Starnes VA, Oyer PE, Stinson EB, Shumway NE. Cytomegalovirus infection is associated with cardiac allograft rejection and atherosclerosis. JAMA. 1989;261(24):3561-3566.

70. Everett JP, Hershberger RE, Norman DJ, Chou S, Ratkovec RM, Cobanoglu A, Ott GY, et al. Prolonged cytomegalovirus infection with viremia is associated with development of cardiac allograft vasculopathy. J Heart Lung Transplant. 1992;11(3 Pt 2):S133-137.

71. Adler SP, Hur JK, Wang JB, Vetrovec GW. Prior infection with cytomegalovirus is not a major risk factor for angiographically demonstrated coronary artery atherosclerosis. J Infect Dis. 1998;177(1):209-212.

72. Ridker PM, Hennekens CH, Buring JE, Kundsin R, Shih J. Baseline IgG antibody titers to Chlamydia pneumoniae, Helicobacter pylori, herpes simplex virus, and cytomegalovirus and the risk for cardiovascular disease in women. Ann Intern Med. 1999;131(8):573-577.

73. Ridker PM, Hennekens CH, Stampfer MJ, Wang F. Prospective study of herpes simplex virus, cytomegalovirus, and the risk of future myocardial infarction and stroke. Circulation. 1998;98(25):2796-2799.

74. Siscovick DS, Schwartz SM, Corey L, Grayston JT, Ashley R, Wang SP, Psaty BM, et al. Chlamydia pneumoniae, herpes simplex virus type 1 , and cytomegalovirus and incident myocardial infarction and coronary heart disease death in older adults : the Cardiovascular Health Study. Circulation. 2000;102(19):2335-2340.

75. Wang GC, Walston J. CMV, cardiovascular disease, and
Frailty. In: Fulop Tetal (eds). Handbook on Immunosenescence: basic understanding and clinical applications 2009; page: 1317-1318.

76. Gattone M, Iacoviello L, Colombo M, Castelnuovo AD, Soffiantino F, Gramoni A, Picco D, et al. Chlamydia pneumoniae and cytomegalovirus seropositivity, inflammatory markers, and the risk of myocardial infarction at a young age. Am Heart J. 2001;142(4):633-640.

77. Ibrahim AI, Obeid MT, Jouma MJ, Moasis GA, Al-Richane WL, Kindermann I, Boehm M, et al. Detection of herpes simplex virus, cytomegalovirus and Epstein-Barr virus DNA in atherosclerotic plaques and in unaffected bypass grafts. J Clin Virol. 2005;32(1):29-32.

78. Hendrix MG, Daemen M, Bruggeman CA. Cytomegalovirus nucleic acid distribution within the human vascular tree. Am J Pathol. 1991;138(3):563-567.

79. Izadi M, Fazel M, Saadat SH, Nasseri MH, Ghasemi M, Dabiri H, Aryan RS, et al. Cytomegalovirus localization in atherosclerotic plaques is associated with acute coronary syndromes: report of 105 patients. Methodist Debakey Cardiovasc J. 2012;8(2):42-46.

80. Nakashima Y, Plump AS, Raines EW, Breslow JL, Ross R. ApoE-deficient mice develop lesions of all phases of atherosclerosis throughout the arterial tree. Arterioscler Thromb. 1994;14(1):133-140.

81. Vliegen I, Duijvestijn A, Grauls G, Herngreen S, Bruggeman C, Stassen F. Cytomegalovirus infection aggravates atherogenesis in apoE knockout mice by both local and systemic immune activation. Microbes Infect. 2004;6(1):17-24.

82. Vliegen I, Herngreen SB, Grauls GE, Bruggeman CA, Stassen FR. Mouse cytomegalovirus antigenic immune stimulation is sufficient to aggravate atherosclerosis in hypercholesterolemic mice. Atherosclerosis. 2005;181(1):39-44.

83. Vliegen I, Stassen F, Grauls G, Blok R, Bruggeman C. MCMV infection increases early T-lymphocyte influx in atherosclerotic lesions in apoE knockout mice. J Clin Virol. 2002;25(Suppl 2):S159-171.

84. Kloppenburg G, de Graaf R, Herngreen S, Grauls G, Bruggeman C, Stassen F. Cytomegalovirus aggravates intimal hyperplasia in rats by stimulating smooth muscle cell proliferation. Microbes Infect. 2005;7(2):164-170.

85. Burnett MS, Durrani S, Stabile E, Saji M, Lee CW, Kinnaird TD, Hoffman EP, et al. Murine cytomegalovirus infection increases aortic expression of proatherosclerotic genes. Circulation. 2004;109(7):893-897.

86. Saikku P, Leinonen M, Mattila K, Ekman MR, Nieminen MS, Makela PH, Huttunen JK, et al. Serological evidence of an association of a novel Chlamydia, TWAR, with chronic coronary heart disease and acute myocardial infarction. Lancet. 1988;2(8618):983-986.

87. Danesh J, Collins R, Peto R. Chronic infections and coronary heart disease: is there a link? Lancet. 1997;350(9075):430-436.

88. Danesh J, Whincup P, Walker M, Lennon L, Thomson A, Appleby P, Wong Y, et al. Chlamydia pneumoniae IgG titres and coronary heart disease: prospective study and meta-analysis. BMJ. 2000;321(7255):208-213. 
89. Danesh J, Whincup P, Lewington S, Walker M, Lennon L, Thomson A, Wong YK, et al. Chlamydia pneumoniae IgA titres and coronary heart disease; prospective study and meta-analysis. Eur Heart J. 2002;23(5):371-375.

90. Ouchi K, Fujii B, Kudo S, Shirai M, Yamashita K, Gondo $\mathrm{T}$, Ishihara $\mathrm{T}$, et al. Chlamydia pneumoniae in atherosclerotic and nonatherosclerotic tissue. J Infect Dis. 2000;181(Suppl 3):S441-443.

91. Kuo C, Campbell LA. Detection of Chlamydia pneumoniae in arterial tissues. J Infect Dis. 2000;181(Suppl 3):S432-436.

92. Maass M, Bartels C, Engel PM, Mamat U, Sievers HH. Endovascular presence of viable Chlamydia pneumoniae is a common phenomenon in coronary artery disease. $\mathrm{J}$ Am Coll Cardiol. 1998;31(4):827-832.

93. Shor A, Kuo CC, Patton DL. Detection of Chlamydia pneumoniae in coronary arterial fatty streaks and atheromatous plaques. S Afr Med J. 1992;82(3):158-161.

94. Liu R, Yamamoto M, Moroi M, Kubota T, Ono T, Funatsu A, Komatsu H, et al. Chlamydia pneumoniae immunoreactivity in coronary artery plaques of patients with acute coronary syndromes and its relation with serology. Am Heart J. 2005;150(4):681-688.

95. Gaydos CA, Summersgill JT, Sahney NN, Ramirez JA, Quinn TC. Replication of Chlamydia pneumoniae in vitro in human macrophages, endothelial cells, and aortic artery smooth muscle cells. Infect Immun. 1996;64(5):16141620.

96. Godzik KL, O'Brien ER, Wang SK, Kuo CC. In vitro susceptibility of human vascular wall cells to infection with Chlamydia pneumoniae. J Clin Microbiol. 1995;33(9):2411-2414.

97. Dechend R, Maass M, Gieffers J, Dietz R, Scheidereit C, Leutz A, Gulba DC. Chlamydia pneumoniae infection of vascular smooth muscle and endothelial cells activates NF-kappaB and induces tissue factor and PAI-1 expression: a potential link to accelerated arteriosclerosis. Circulation. 1999;100(13):1369-1373.

98. Baldwin AS, Jr. Series introduction: the transcription factor NF-kappaB and human disease. J Clin Invest. 2001;107(1):3-6.

99. Mayr M, Metzler B, Kiechl S, Willeit J, Schett G, Xu Q, Wick G. Endothelial cytotoxicity mediated by serum antibodies to heat shock proteins of Escherichia coli and Chlamydia pneumoniae: immune reactions to heat shock proteins as a possible link between infection and atherosclerosis. Circulation. 1999;99(12):1560-1566.

100. Zhu J, Katz RJ, Quyyumi AA, Canos DA, Rott D, Csako G, Zalles-Ganley A, et al. Association of serum antibodies to heat-shock protein 65 with coronary calcification levels: suggestion of pathogen-triggered autoimmunity in early atherosclerosis. Circulation. 2004;109(1):36-41.

101. Lin FY, Lin YW, Huang CY, Chang YJ, Tsao NW, Chang $\mathrm{NC}, \mathrm{Ou} \mathrm{KL}$, et al. GroEL1, a heat shock protein 60 of Chlamydia pneumoniae, induces lectin-like oxidized low-density lipoprotein receptor 1 expression in endothelial cells and enhances atherogenesis in hypercholesterolemic rabbits. J Immunol. 2011;186(7):4405-4414.

102. Naiki Y, Sorrentino R, Wong MH, Michelsen KS, Shi- mada K, Chen S, Yilmaz A, et al. TLR/MyD88 and liver $\mathrm{X}$ receptor alpha signaling pathways reciprocally control Chlamydia pneumoniae-induced acceleration of atherosclerosis. J Immunol. 2008;181(10):7176-7185.

103. Schroder NW, Schumann RR. Single nucleotide polymorphism of Toll-like receptors and susceptibility to infectious disease. Lancet infect dis. 2005;5:156-164.

104. Song Z, Brassard P, Brophy JM. A meta-analysis of antibiotic use for the secondary prevention of cardiovascular diseases. Can J Cardiol. 2008;24(5):391-395.

105. Epstein SE, Zhu J, Najafi AH, Burnett MS. Insights into the role of infection in atherogenesis and in plaque rupture. Circulation. 2009;119(24):3133-3141.

106. Blessing E, Campbell LA, Rosenfeld ME, Chesebro B, Kuo CC. A 6 week course of azithromycin treatment has no beneficial effect on atherosclerotic lesion development in apolipoprotein E-deficient mice chronically infected with Chlamydia pneumoniae. J Antimicrob Chemother. 2005;55(6):1037-1040.

107. Campbell LA, Rosenfeld ME. Persistent C. pneumoniae infection in atherosclerotic lesions: rethinking the clinical trials. Front Cell Infect Microbiol. 2014;4:34.

108. Momiyama Y, Hirano R, Taniguchi H, Nakamura H, Ohsuzu F. Effects of interleukin-1 gene polymorphisms on the development of coronary artery disease associated with Chlamydia pneumoniae infection. J Am Coll Cardiol. 2001;38(3):712-717.

109. Rosenfeld ME, Campbell LA. Pathogens and atherosclerosis: update on the potential contribution of multiple infectious organisms to the pathogenesis of atherosclerosis. Thromb Haemost. 2011;106(5):858-867.

110. Prasad A, Zhu J, Halcox JP, Waclawiw MA, Epstein SE, Quyyumi AA. Predisposition to atherosclerosis by infections: role of endothelial dysfunction. Circulation. 2002;106(2):184-190.

111. Zhu J, Quyyumi AA, Norman JE, Csako G, Waclawiw MA, Shearer GM, Epstein SE. Effects of total pathogen burden on coronary artery disease risk and C-reactive protein levels. Am J Cardiol. 2000;85(2):140-146.

112. Rupprecht HJ, Blankenberg S, Bickel C, Rippin G, Hafner G, Prellwitz W, Schlumberger W, et al. Impact of viral and bacterial infectious burden on long-term prognosis in patients with coronary artery disease. Circulation. 2001;104(1):25-31.

113. Kaplan M, Yavuz SS, Cinar B, Koksal V, Kut MS, Yapici F, Gercekoglu H, et al. Detection of Chlamydia pneumoniae and Helicobacter pylori in atherosclerotic plaques of carotid artery by polymerase chain reaction. Int $\mathrm{J}$ Infect Dis. 2006;10(2):116-123.

114. Prochnau D, Straube E, Figulla HR, Rodel J. Supra-additive expression of interleukin-6, interleukin- 8 and basic fibroblast growth factor in vascular smooth muscle cells following coinfection with Chlamydia pneumoniae and cytomegalovirus as a novel link between infection and atherosclerosis. Can J Infect Dis Med Microbiol. 2012;23(2):e26-30.

115. Sessa R, Pietro MD, Filardo S, Turriziani O. Infectious burden and atherosclerosis: A clinical issue. World J Clin Cases. 2014;2(7):240-249. 